Research Article

www.ijrap.net

\title{
AN ETIOPATHOLOGICAL AND THERAPEUTIC STUDY ON STHULA PRAMEHI W.S.R. TO NIDDM
}

Agarwal Vivek*

Department of Rog Nidan, M.S.M. Institute of Ayurveda, Sonipat, Haryana, India

Received on: 14/05/12 Revised on: 26/06/12 Accepted on: 20/08/12

\begin{abstract}
*Corresponding author Haryana 131305 India Email- drvivek91@gmail.com

DOI: 10.7897/2277-4343.03520

Published by Moksha Publishing House. Website www.mokshaph.com

All rights reserved.
\end{abstract}

Dr. Vivek Agarwal, Assistant Professor, Dept. of Rog Nidan, MSM Institute of Ayurveda, BPS Women University, Khanpur Kalan, Dist. Sonipat,

\section{ABSTRACT}

Declaration of diabetes mellitus as an epidemic by World Health Organization indicates alarming proportions. The rates of diabetes have increased markedly over the last 50 years in parallel with obesity. The foremost reason for such a wide spread diabetes mellitus especially NIDDM (Sthula Pramehi) is the ignorance of well balanced life style principles. Obesity is extremely important influences in NIDDM. Approximately $80 \%$ of NIDDM are obese with abdominal obesity having greater impact. The main aim of present research work was to manage the Sthula Pramehi person (obese diabetic) with a single drug combination i.e. Mehari Yoga (hypothetical). There were several works done on obesity and diabetes mellitus separately. Both have same etiological factors and requires almost same mode of management hence it was necessary to control the Sthula Pramehi (NIDDM) with single drug combination which consists of medohara and pramehaghna drugs. In present study, 30 known Sthula Pramehi persons (NIDDM) were selected and divided in to three groups 10 of each. Group A patients given allopathic control, Group B patients given allopathic control and Mehari Yoga and Group C patients given Mehari Yoga only. Results after one month drug trial were noted, Group B showed better results of improvement than Group A and C.

Keywords: Non Insulin Dependent Diabetes Mellitus, Mehari Yoga, Sthula Pramehi.

\section{INTRODUCTION}

The $21^{\text {st }}$ century, with it continuous changing life styles, environment and dietary habits have made man the victim of many diseases, Sthula Prameha (Non Insulin dependent diabetes mellitus) is one of them. Sthaulya is one of the most effective disease, which affect someone social, physical and mental features. As per modern view it is a precursor to coronary heart disease, High blood pressure, diabetes mellitus and osteoarthritis, which have been recognized as the leading killer disease of the millennium. In 2000, there were an estimated 175 million people with diabetes world wide and by 2030 the projected estimate of diabetes 354 million, 1 out of 20 people in new millennium will be diabetic.

In ayurvedic literature, on the basis of body constitution or structure, Prameha patients are divided into two groups. Group 1. Sthula and powerful and Group 2. Krisha and weak. The Sthula or obese Prameha patients have more strength as compared to Krisha or asthenic patients $^{1}$

According to Ayurveda, samprapti vightana is the main basis for management of the diseases. Under the samprapti of Prameha, Acharya Sushruta has mentioned Prameha is a kapha dosha predominant disease and the main dushyas are meda and kleda ${ }^{2}$

In atisthaulya meda act as a dosha and there is medovriddhi which on further increase causes obstructions of the channels due to meda, leading to the manifestation of the complications like Prameha, Prameha pidika, Bhagandra etc.

In brief aetiology, Charaka has mentioned that as the birds are attracted towards the trees where their nest lies, similarly Prameha affects persons who are voracious eater, less enthusiastic, have aversion to bath and physical as well mental exercise, over corpulent (atisthaulya) and over unctuous (atisnigdha) ${ }^{3}$.

Obesity develops as a result of an excessive consumption of calories relative to energy expenditure. The hyperinsulinemia of obesity could result from prolonged intake of a diet high in calories, particularly carbohydrates or the obese state itself may be related to hyperinsulinemia which reduces the glucose entry in cell and causes Hyperglycemia (NIDDM) ${ }^{6}$.

Because of the apparent danger and short comings of allopathic medicines, in the recent year, in the global prospective there is shift towards the use of medicines of herbal origin with respect to global perspective. WHO has already approved the use of traditional medicines as a part of health programme So, the main object of present research work is to manage the Sthula Pramehi (obese diabetics) person with a single combination of the drug i.e. Mehari Yoga (hypothetical) because obesity is associated with carbohydrate intolerance, insulin resistance and hyperinsulinism, which are the features of Non insulin dependent diabetes mellitus (NIDDM).

Present research work has been undertaken with the following aims and objectives-

- To assess the presence of various etiological factors explained by Ayurveda in the diagnosed cases of Sthula Pramehi (NIDDM).

- To establish a relationship of Nidans mentioned in Ayurvedic and Modern literature.

- To assess the efficacy of "Mehari Yoga" (Hypothetical) in management of Sthula Pramehi.

- To analyses the pathogenesis of Prameha from Sthaulya. 


\section{MATERIAL AND METHODS}

Selection of Patients

Patients for therapeutic drug trial was selected from the OPD and IPD of the Hospital, National Institute of Ayurveda, Jaipur after screening them as per Ayurvedic and Modern criteria for Sthula Pramehi. Selection was carried out according to relevant history, sign, symptoms and Laboratory investigations including Body Mass Index for Sthula persons and the study carried out as per Ethical Committee clearance NIA/PG/RV/2001/475875/16.04.2003.

\section{Inclusion Criteria}

- Patients in the age group between 35 to 65 years of either sex.

- Diagnosed cases of NIDDM with BMI>25.

Exclusion Criteria

- Patients of age less than 35 years and above 65 years.

- Patients of Insulin dependent diabetes mellitus.

- Patients taking drugs like corticosteroids, tricyclic antidepressant, cycloheptadine which leads to weight gain.

\section{Selection of Drug}

The herbal formulation "Mehari Yoga" (hypothetical) is selected to assess the efficacy in Sthula Pramehi persons. All drugs, used in Mehari Yoga are stated to possess the Medohara and Pramehara properties as mentioned in various Ayurvedic classics and also in various Nighantus. Ingredients of this drug (Mehari Yoga) ${ }^{4,5}$ are as follows Aamrasthi majja, Jambu seeds, Karvellaka fruit pulp, Nimba nimboli, Bilwa fruit pulp, Devadaru heartwood, Daruharidra heartwood, Palandu seeds, Amalaki fruit pulp Reasoning for Selection of Drug

The main aim to select this drug combination is to control the Sthaulya and Prameha roga with the single drug combination, because both the Sthaulya and Prameha are the complication of each other and has almost require the same mode of treatment, because the aetiological factors mentioned in context to the Sthaulya and Prameha are almost the same and both the diseases are considered as Santarpanjanya vyadhi in Ayurveda.

\section{Preparation of Drug}

Above mentioned all the nine ingredients were taken in equal quantity and prepared in the form of churna in the pharmacy of National Institute of Ayurveda, Jaipur.

\section{Vehicle of Drug}

Luke warm water was given as Anupana. The importance of giving luke warm water was that it is kapha, meda, vata, aama nasaka, agnidipana and also has role in purification of vasti ${ }^{2}$

\section{Administration of Drug}

30 clinically diagnosed Sthula Pramehi (Obese diabetics) patients were randomly divided in to three groups -

Group A: 10 Sthula Pramehi patients were recommended allopathic medicine for one month as a control group.

Group B: 10 Sthula Pramehi patients were recommended allopathic medicine along with Mehari Yoga 5-5gm. twice a day with luke warm water before 15 minutes of meal for one month as a combined group.

Group C: 10 Sthula Pramehi patients were recommended only Mehari Yoga 5-5gm. twice a day with Luke warm water before 15 minutes of meal for one month as a only Ayurvedic medicine group.

Follow up study

- Patients were followed up after 15 days and one month.

- Laboratory investigations were repeated after complete treatment.

- Improvement and other effects were noted.

Note- No side or toxic effects of 'Mehari Yoga' was reported by any individual during trial.

\section{Criteria for Assessment}

After the completion of the treatment, the results were assessed by adopting the following criteria -

- Improvement in symptoms of disease on the basis of subjective assessment parameters.

- Improvement in laboratory investigations (i.e. reduce levels) on the basis of laboratory reports.

- Reduction in Objective assessment parameters.

Hence, for clinical evaluation the criteria can be divided into two types:

- Subjective assessment

- Objective assessment

\section{Subjective Assessment}

Table 1: Chala Sphiga Udara Stana (CSUS) Assessment

\begin{tabular}{|c|c|}
\hline \multicolumn{1}{|c|}{ Assessment Criteria } & Score \\
\hline Absent & 0 \\
\hline $\begin{array}{c}\text { Chala Sphiga Udara Stana only felt by patient him/her } \\
\text { self }\end{array}$ & 1 \\
\hline $\begin{array}{c}\text { Chala Sphiga Udara Stana only on brisk walking which is } \\
\text { felt by patient himself }\end{array}$ & 2 \\
\hline $\begin{array}{c}\text { Chala Sphiga Udara Stana observable by others on brisk } \\
\text { walking }\end{array}$ & 3 \\
\hline Chala Sphiga Udara Stana even on normal walk & 4 \\
\hline
\end{tabular}

Table 2: Ayathopachaya [Disproportionate body] Assessment

\begin{tabular}{|c|c|}
\hline Assessment Criteria & Score \\
\hline No Ayathopachaya & 0 \\
\hline Partial /Mild Ayathopachaya & 1 \\
\hline Moderate Ayathopachaya & 2 \\
\hline Profuse Ayathopachaya & 3 \\
\hline Extensive Ayathopachaya & 4 \\
\hline
\end{tabular}

Table 3: Prabhoot Mootrata [Polyurea] Assessment

\begin{tabular}{|c|c|c|}
\hline Frequency of Urine & Quantity of Urine & Score \\
\hline $\begin{array}{c}\text { Frequency 4-6 times /24 } \\
\text { hours }\end{array}$ & Quantity 1.1-2.0 liter & 0 \\
\hline $\begin{array}{c}\text { Frequency 7-9 times /24 } \\
\text { hours }\end{array}$ & Quantity 2.1-3.0 liter & 1 \\
\hline $\begin{array}{c}\text { Frequency 10-12 times } \\
/ 24 \text { hours }\end{array}$ & Quantity 3.1-4.0 liter & 2 \\
\hline $\begin{array}{c}\text { Frequency 13-15 times } \\
/ 24 \text { hours }\end{array}$ & Quantity 4.1-5.0 liter & 3 \\
\hline $\begin{array}{c}\text { Frequency }>15 \text { times /24 } \\
\text { hours }\end{array}$ & Quantity 5.1-6.0 liter & 4 \\
\hline
\end{tabular}

Table 4: Aavil Mootrata [Turbidity in Urine] Assessment

\begin{tabular}{|c|c|c|c|c|}
\hline $\begin{array}{c}\text { Specific } \\
\text { gravity }\end{array}$ & $\begin{array}{c}\text { Urine } \\
\text { sugar }\end{array}$ & Albumin & Total & Score \\
\hline $1020-1025(0)$ & Nil (0) & Nil (0) & 0 & 0 \\
\hline $1026-1030(1)$ & $+(1)$ & $+(1)$ & $1-3$ & 1 \\
\hline $1031-1035(2)$ & $++(2)$ & $++(2)$ & $4-6$ & 2 \\
\hline $1036-1040(3)$ & $+++(3)$ & $+++(3)$ & $7-9$ & 3 \\
\hline $1041-1045(4)$ & $++++(4)$ & $++++(4)$ & $10-12$ & 4 \\
\hline
\end{tabular}


Table 5: Pipasa Adhikya [Polydipsia] Assessment Assessment Criteria Absent (Taking 8-10 glass of water daily) Patient is taking 10-15 glass/day and getting satisfaction Patient is taking 15-20 glass/day and not getting satisfaction Patient is taking 20-25 glass/day and not getting satisfaction Patient is unable to have a sound sleep due to his/her thirst

Table 6: Kshuda Adhikya [Polyphagia] Assessment

\begin{tabular}{|c|c|}
\hline Assessment Criteria & Score \\
\hline 2 Chapati / Meal & 0 \\
\hline 3-4 Chapati / Meal & 1 \\
\hline 4-5 Chapati / Meal & 2 \\
\hline 6 Chapati / Meal & 3 \\
\hline > 6 Chapati / Meal & 4 \\
\hline
\end{tabular}

Table 7: Swedadhikya [Excessive Sweating] Assessment

\begin{tabular}{|c|c|}
\hline Assessment Criteria & Score \\
\hline Normal Perspiration & 0 \\
\hline Mild after exertion & 1 \\
\hline Increased Perspiration after little exertion & 2 \\
\hline Heavy Perspiration after little exertion & 3 \\
\hline Perspiration without exertion & 4 \\
\hline
\end{tabular}

Table 8: Daurbalya [Weakness] Assessment

\begin{tabular}{|c|c|}
\hline Assessment Criteria & Score \\
\hline No Tiredness & 0 \\
\hline Mild after work & 1 \\
\hline Tired after little work & 2 \\
\hline Works with great difficulty & 3 \\
\hline Having great difficulty for doing little work & 4 \\
\hline
\end{tabular}

Table 9: Aalasya [Lassitude] Assessment

\begin{tabular}{|c|c|}
\hline Assessment Criteria & Score \\
\hline Normally active & 0 \\
\hline Hesitate to start work but once started complete it & 1 \\
\hline Starts but does not complete it & 2 \\
\hline Doesn't have desire, work under compulsion & 3 \\
\hline Doesn't starts work & 4 \\
\hline
\end{tabular}

Table 10: Atinidra [Excessive Sleep] Assessment

\begin{tabular}{|c|c|}
\hline Assessment Criteria & Score \\
\hline $6-8$ hours /day sleep & 0 \\
\hline 8-10 hours /day sleep & 1 \\
\hline $10-12$ hours /day sleep & 2 \\
\hline $12-14$ hours /day sleep & 3 \\
\hline$>14$ hours /day sleep & 4 \\
\hline
\end{tabular}

Table 11: Vibhanda [Constipation] Assessment Assessment Criteria

\begin{tabular}{|c|c|}
\hline Assessment Criteria & Score \\
\hline Stool passes as per normal schedule & 0 \\
\hline $\begin{array}{c}\text { Passes stool with strain, sometimes takes purgative } \\
\text { purgative }\end{array}$ & 1 \\
\hline $\begin{array}{c}\text { Passes stool after gap of one day, normal purgative does } \\
\text { not work }\end{array}$ & 3 \\
\hline
\end{tabular}

Table 12: Malavritta Jihwa [Coated Tongue] Assessment

\begin{tabular}{|c|c|}
\hline Assessment Criteria & Score \\
\hline No Coating on tongue & 0 \\
\hline Mild Coating on tongue & 1 \\
\hline Moderate Coating on tongue & 2 \\
\hline Heavy Coating on tongue & 3 \\
\hline
\end{tabular}

Table 13: Karpaada Daha [Burning sensation in hand and foot] Assessment

\begin{tabular}{|c|c|}
\hline Assessment Criteria & Score \\
\hline Absent & 0 \\
\hline Occasional Kapaada daha & 1 \\
\hline Continuous Karpaada daha & 2 \\
\hline $\begin{array}{c}\text { Continuous Karpaada daha and required some } \\
\text { medication }\end{array}$ & 3 \\
\hline $\begin{array}{c}\text { Continuous Karpaada daha but does not get relief by } \\
\text { medication }\end{array}$ & 4 \\
\hline
\end{tabular}

Table 14: Madhurasyata [Sweetness of Mouth] Assessment

\begin{tabular}{|c|c|}
\hline Assessment Criteria & Score \\
\hline No sweetness in mouth & 0 \\
\hline Mild sweetness in mouth & 1 \\
\hline Moderately sweetness in mouth & 2 \\
\hline Always feels sweetness in mouth & 3 \\
\hline
\end{tabular}

Table 15: Tandra [Drowsiness] Assessment

\begin{tabular}{|c|c|}
\hline Assessment Criteria & Score \\
\hline No drowsiness & 0 \\
\hline Mild drowsiness but able to do usual work & 1 \\
\hline Moderate drowsiness but able to do usual work with errors & 2 \\
\hline Severe drowsiness which hampers usual work & 3 \\
\hline Patient unable to do any work because of drowsiness & 4 \\
\hline
\end{tabular}

Table 16: Krichchha Vyavayata [Sexual dysfunction] Assessment

\begin{tabular}{|c|c|}
\hline Assessment Criteria & Score \\
\hline Absent & 0 \\
\hline Mild loss of Libido & 1 \\
\hline Moderate loss of Libido & 2 \\
\hline Severe loss of Libido & 3 \\
\hline Complete loss of Libido & 4 \\
\hline
\end{tabular}

Table 17: Sandhi Shula [Joint Pain] Assessment

\begin{tabular}{|c|c|}
\hline Assessment Criteria & Score \\
\hline No Pain & 0 \\
\hline Pain in Joint, routine movements normal & 1 \\
\hline Pain in Joint, slight limitations of movements & 2 \\
\hline $\begin{array}{c}\text { Pain in Joint, limitations of movement with very } \\
\text { reduce activity }\end{array}$ & 3 \\
\hline
\end{tabular}

\section{Objective Assessment}

Table 18: Assessment of Body Mass Index [B.M.I.]

\begin{tabular}{|c|c|}
\hline Assessment Criteria & Score \\
\hline $18.5-24.9$ & 0 \\
\hline $25-29.9$ & 1 \\
\hline $30-34.9$ & 2 \\
\hline $35-39.9$ & 3 \\
\hline$>40$ & 4 \\
\hline
\end{tabular}

Table 19: Assessment of Waist Circumference

\begin{tabular}{|c|c|c|}
\hline \multicolumn{2}{|c|}{ Assessment Criteria } & Score \\
\hline In Male & In Female & \\
\hline $30-32$ inches & $24-26$ inches & 0 \\
\hline $33-35$ inches & $27-29$ inches & 1 \\
\hline $36-38$ inches & $30-32$ inches & 2 \\
\hline $39-41$ inches & $33-35$ inches & 3 \\
\hline$>42$ inches & $>35$ inches & 4 \\
\hline
\end{tabular}

Table 20: Assessment of Hip Circumference

\begin{tabular}{|c|c|c|}
\hline \multicolumn{2}{|c|}{ Assessment Criteria } & Score \\
\hline In Male & In Female & \\
\hline $30-32$ inches & $30-32$ inches & 0 \\
\hline $33-35$ inches & $33-35$ inches & 1 \\
\hline $36-38$ inches & $36-38$ inches & 2 \\
\hline $39-41$ inches & $39-41$ inches & 3 \\
\hline$>42$ inches & $>42$ inches & 4 \\
\hline
\end{tabular}




\section{OBSERVATIONS}

Table 21: Age wise distribution of Patients

\begin{tabular}{|c|c|c|c|c|c|c|}
\hline S.No. & \multirow{2}{*}{$\begin{array}{c}\text { Age } \\
\text { (In years) }\end{array}$} & \multicolumn{3}{|c|}{ Number of Patients } & \multirow{2}{*}{ Total } & \% \\
\cline { 3 - 5 } & $35-45$ & 2 & 7 & 4 & 13 & 43.33 \\
\hline 1. & $46-55$ & 4 & 1 & 5 & 10 & 33.33 \\
\hline 2. & $56-65$ & 4 & 2 & 1 & 07 & 23.33 \\
\hline 3. & 10 & 10 & 10 & 30 & 100 \\
\hline \multicolumn{2}{|r|}{ Total } & &
\end{tabular}

Table 22: Distribution based on Family History of Obese Diabetics Patients

\begin{tabular}{|c|c|c|c|c|c|c|}
\hline \multirow{2}{*}{ S.No. } & \multirow{2}{*}{ Family History } & \multicolumn{3}{|c|}{ Number of Patients } & \multirow{2}{*}{ Total } & \multirow{2}{*}{$\%$} \\
\cline { 3 - 5 } & & Group-A & Group-B & Group-C & & \\
\hline 1. & Present & 5 & 7 & 7 & 19 & 63.33 \\
\hline 2. & Absent & 5 & 3 & 3 & 11 & 36.66 \\
\hline \multicolumn{2}{|r|}{ Total } & 10 & 10 & 10 & 30 & 100 \\
\hline
\end{tabular}

\section{RESULTS}

Table 23: Comparative improvement of Lipid Profile in all groups

\begin{tabular}{|c|c|c|c|c|}
\hline Groups & $\begin{array}{c}\text { Relief in } \\
\mathbf{\%}\end{array}$ & $\begin{array}{c}\text { 't' } \\
\text { Value }\end{array}$ & $\begin{array}{c}\text { 'p' } \\
\text { Value }\end{array}$ & Result \\
\hline $\mathrm{A}$ & 14.42 & 4.3452 & $<0.01$ & Significant \\
\hline $\mathrm{B}$ & 25.94 & 6.0237 & $<0.001$ & Highly Significant \\
\hline $\mathrm{C}$ & 21.42 & 6.0505 & $<0.001$ & Highly Significant \\
\hline
\end{tabular}

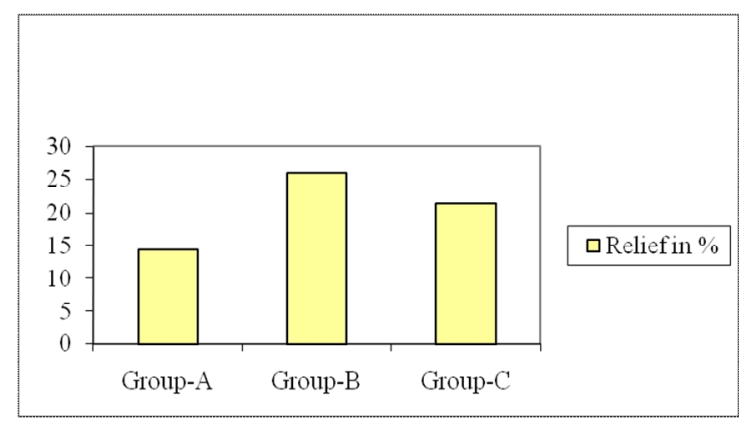

Graph 1: Shows Comparative Lipid Profile improvement in all groups

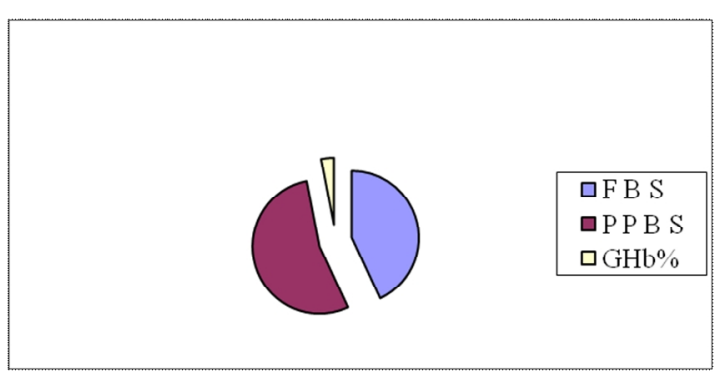

Graph 2: Shows Blood Sugar improvement in group-A
Table 24: Over all comparative improvement in all groups

\begin{tabular}{|c|c|c|c|}
\hline Observations & $\begin{array}{c}\text { Group } \\
\text { A }\end{array}$ & $\begin{array}{c}\text { Group } \\
\text { B }\end{array}$ & $\begin{array}{c}\text { Group } \\
\text { C }\end{array}$ \\
\hline Subjective Improvement & $49.69 \%$ & $59.54 \%$ & $44.39 \%$ \\
\hline Objective Improvement & $3.492 \%$ & $7.3075 \%$ & $7.260 \%$ \\
\hline Investigation Improvement & $17.03 \%$ & $25.93 \%$ & $18.64 \%$ \\
\hline
\end{tabular}

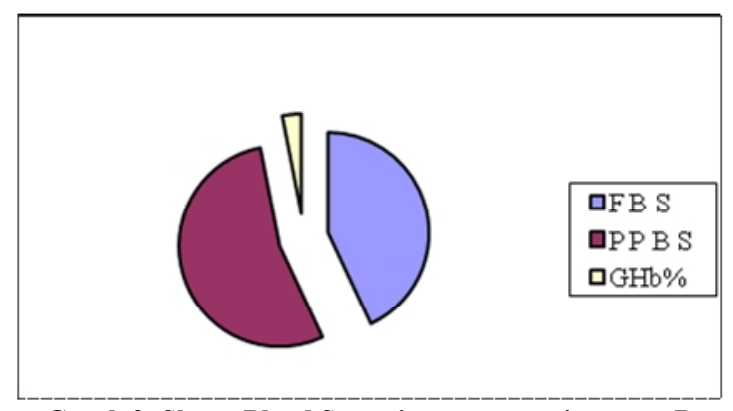

Graph 3: Shows Blood Sugar improvement in group-B

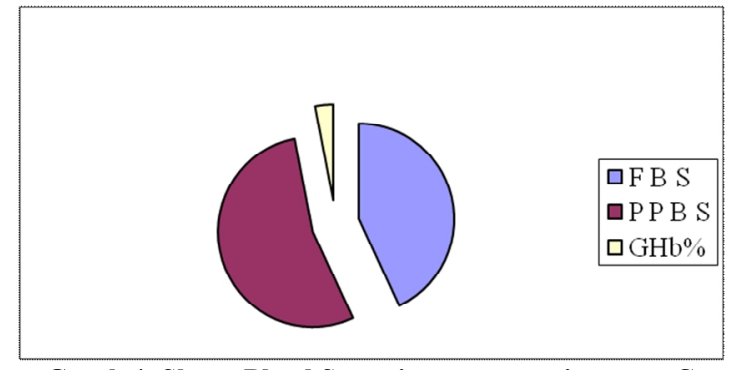

Graph 4: Shows Blood Sugar improvement in group-C

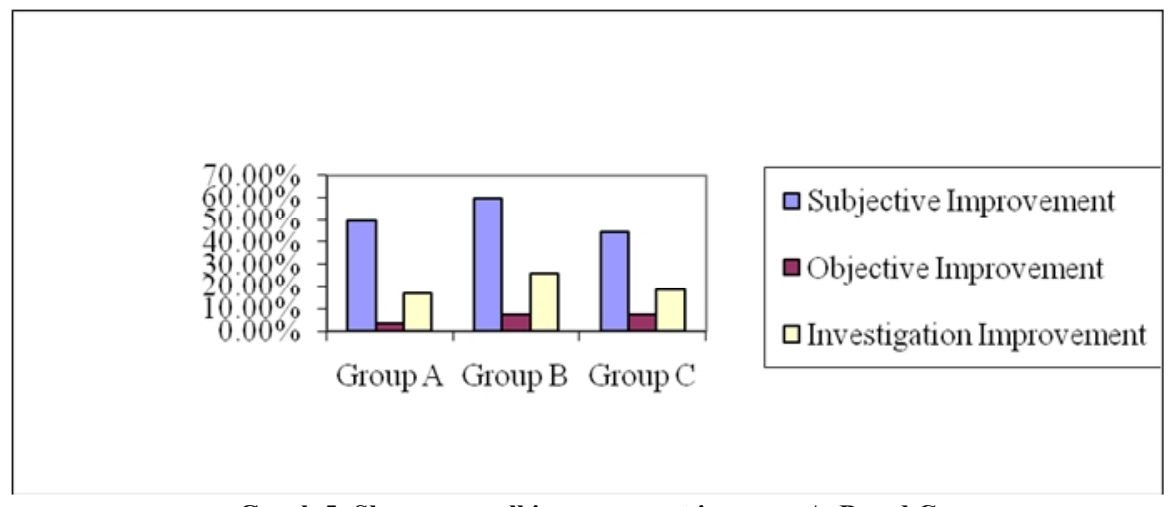

Graph 5: Shows over all improvement in group A, B and C 


\section{DISCUSSION}

\section{Discussion on Subsidence of Symptoms}

The highest percentage of symptoms found in patients were Chala sphiga udara stana (CSUS), Prabhoot mootrata, Kshudhadhikya (100\% each), Daurbalya (96.66\%), Shula, Pipasadhikya, Swedatipravriti (93.33\% each), Kar-pada Daha and Tandra (90\% each) While least percentage was of Vibandh $(30 \%)$ in all the three group of study.

Group - A shows maximum percentage improvement in Daurbalya (68.18\%), Pipasadhikya (61.90\%), and Malavritta Jihwa (61.53\%) Kshudhadhikya (61.11\%) and Mukhmadhurya $(58.33 \%)$ while minimum percentage of improvement was in Krichvyavayata (13.33\%), but over all study shows symptomatic improvement in Group A was $49.69 \%$.

Group - B shows maximum percentage improvement in Daurbalya (82.60\%), Aavil Mootrata (80\%), Kar-pada Daha (79.16\%), Malavritta Jihwa (72.72\%), Kshudhadhikya (68.42\%), and Pipasadhikya (62.50\%), and Ayathopachaya (62.50\%) while minimum percentage of improvement in Krichvyavayata (37.50\%) and Vibandh $(25 \%)$ but over all study shows symptomatic improvement in Group B was 59.54\%.

Group - C shows maximum percentage improvement in Daurbalya (62.50\%), Kar-pada Daha (58.82\%), Malavritta Jihwa (54.54\%) and Kshudhadhikya (56.25\%), while minimum percentage of improvement in Krichvyavayata (16.66\%) but over all study shows symptomatic improvement in Group C was $44.39 \%$.

Over all results on the basis of improvement percentage showed that group - B had better therapeutic effect than group A and C. This suggests that Mehari Yoga shows better results with allopathic medicine on the Symptomatic Parameters.

\section{Discussion on Physical Examination}

In physical examination we took the following parameters i.e. Body weight, Body mass index, Waist circumference and Hip circumference.

In Group - A, the improvement percentage in Body weight $(2.24 \%)$, Body mass index $(2.29 \%)$, Waist circumference $(4.65 \%)$ and in Hip circumference (4.79\%). Over all percentage of improvement is 3.492\%.

In Group - B, the improvement percentage in Body weight $(5.85 \%)$, Body mass index (5.93\%), Waist circumference $(8.66 \%)$ and in Hip circumference (8.79\%). Over all percentage of improvement is $7.3075 \%$. In Group - C, the improvement percentage in Body weight $(5.95 \%)$, Body mass index $(5.90 \%)$, Waist circumference $(8.44 \%)$ and in Hip circumference $(8.75 \%)$. Over all percentage of improvement is $7.260 \%$.

On the basis of improvement percentage overall results showed that group B and C have better therapeutic effect than of group A. This suggests that Mehari Yoga shows better results with or with out allopathic medicine on the parameters of physical examination.

\section{Discussion on Drug}

For the present study we have selected the drug combination i.e. "Mehari Yoga" (Hypothetical) with the help of taking references from the various texts. The drugs in this Yoga are easily available and having high degree of clinical effects mentioned in Sthula Pramehi Persons.

The majority of drugs having Tikta kashaya rasa, Katu vipaka and Kapha pitta shamaka property. This combination of drug gives statistically highly significant results mainly on physical examination parameters, lipid profile and sugar level. This is because of the lekhana karma of the majority of contents of Mehari Yoga.

The over all study showed that this combination of drug showed good results on Sthula Pramehi Persons because it controls both Sthaulya and Prameha with a single preparation.

All the patients tolerated medicines very well and no side effects or toxicity effects of any of these drugs were reported by any of the patients registered in current series of 30 patients of Sthula Prameha Roga, suggesting that the drugs selected for the current clinical trial are absolutely safe for internal use by the patient, but the churna form was not palatable to some patients for administration of drug.

\section{Discussion on Investigations}

The haematological investigations i.e. Haemoglobin, Total Leukocyte Count, Differential Leukocyte Count and Erythrocyte Sedimentation Rate showed statistically insignificant results in all the three groups. Blood Urea in all the three groups showed statistically insignificant results.

In Group A, mean Fasting Blood Sugar reduction was $14.3 \%(\mathrm{p}<0.01)$ while mean Post Prandial Blood Sugar reduction was $19.2 \%(\mathrm{p}<0.01)$ and mean Glycosylated Haemoglobin reduction was $8.57 \%(\mathrm{p}<0.01)$. All these showed statistically significant improvement.

Mean Fasting Urine Sugar (FUS) reduction was 62.5\% $(\mathrm{p}<0.01)$ while mean Post Meal Urine Sugar (PPUS) reduction was $52.1 \%(\mathrm{p}<0.001)$. FUS showed statistically significant results while PMUS showed statistically highly significant results.

Mean Lipid Profile reduction was $14.42 \%(p<0.01)$; it shows the significant results on the basis of statistical analysis.

In Group B, mean Fasting Blood Sugar reduction was 24.7\% $(\mathrm{p}<0.001)$ while mean Post Prandial Blood Sugar reduction was $25.2 \%(\mathrm{p}<0.001)$ and mean Glycosylated Haemoglobin reduction was $12.5 \%(\mathrm{p}<0.01)$. FBS and PPBS showed statistically highly significant improvement while $\mathrm{GHb} \%$ showed significant results.

Mean Fasting Urine Sugar (FUS) reduction was 91.1\% $(\mathrm{p}<0.02)$ while mean Post Meal Urine Sugar (PMUS) reduction was $72.7 \%(\mathrm{p}<0.001)$. FUS showed statistically insignificant results while PMUS showed statistically highly significant results.

Mean Lipid Profile reduction was 25.94\% ( $<<0.001)$; it shows the highly significant results on the basis of statistical analysis.

In Group C, mean Fasting Blood Sugar reduction was $16.9 \%(\mathrm{p}<0.001)$ while mean Post Prandial Blood Sugar reduction was $14.9 \%(\mathrm{p}<0.001)$ and mean Glycosylated Haemoglobin reduction was $8.18 \%(\mathrm{p}<0.01)$. FBS and PPBS showed statistically highly significant improvement while $\mathrm{GHb} \%$ showed significant results.

Mean Fasting Urine Sugar (FUS) reduction was 52.9\% $(\mathrm{p}<0.02)$ while mean Post Meal Urine Sugar (PMUS) 
reduction was $48.0 \%(\mathrm{p}<0.001)$. FUS showed statistically insignificant results while PMUS showed statistically highly significant results.

Mean Lipid Profile reduction was $21.42 \%(\mathrm{p}<0.001)$; it shows the highly significant results on the basis of statistical analysis.

\section{CONCLUSION}

Study showed that group $\mathrm{B}$ with symptomatic improvement $(59.54 \%)$ and laboratory improvement $(25.93 \%)$ had better results in comparison to group A with symptomatic improvement (49.69\%) and laboratory improvement $(17.03 \%)$ and group $\mathrm{C}$ with symptomatic improvement $(44.39 \%)$ and laboratory improvement $(18.64 \%)$.

The present clinical trial is a limited research work with limited resources on a very small number of patients. It is proposed that the same project should be undertaken on a large series of patients with more scientific parameters to obtain concrete conclusion.

\section{ACKNOWLEDGEMENT}

I would like to thank Prof. Loknath Sharma, Ex. HOD of Rog Nidan, National Institute of Ayurveda Jaipur, for his valuable guidance, precious support and priceless blessings showered on each and every step, right from the commencement.

\section{REFERENCES}

1. Charaka Samhita Uttrardh by Pt. Kashinath Shastri and Dr. Gorakhnath Chaturvedi, Reprint 1998, Published by Chaukhambha Bharti Academy, Varanasi, Chikitsa Sthan 6/15, pp 235

2. Sushruta Samhita Purvardh with Hindi translation by Ambika Dutta Shastri, $14^{\text {th }}$ Edition, 2003, Chaukhambha Sanskrit Sansthan Office, Varanasi, Nidan Sthan 6/14 pg 251, Sutra Sthan.45/39 pp 171

3. Charaka Samhita Purvardh by Pt. Kashinath Shastri and Dr. Gorakhnath Chaturvedi, $22^{\text {nd }}$ edition 1996, Published by Chaukhambha Bharti Academy, Varanasi, Nidan Sthan 4/50-51, pp 640

4. Dravya Guna Vigyan II by Acharya P.V.Sharma, $2^{\text {nd }}$ Edition, 1998, Chaukhambha Bharti Academy, Varanas Chapter / pp -8/284,285, $298,2 / 57,5 / 186,1 / 25,27,6 / 222,9 / 341$

5. Bhava Prakash by Shri Bhava Mishra II, $5^{\text {th }}$ Edition, 1998, Chaukhambha Sanskrit Sansthan, Varanasi, pp 331, $570,683,328,274,627,196,119,10$

6. Davidson's Principles and Practice of Medicine by C.R.W.Edwards, I.A.D.Bouchier, $19^{\text {th }}$ Edition, 2002, Churchill Livingstone, New York. Pp 303

\section{Cite this article as:}

Agarwal Vivek. An etiopathological and therapeutic study on Sthula pramehi w.s.r. to NIDDM. Int. J. Res. Ayur. Pharm. 2012; 3(5):676-681 